\title{
Insufficient Concern: A Unified Conception of Criminal Culpability
}

\author{
Larry Alexander $\dagger$
}

\section{INTRODUCTION}

Most criminal law theorists and the criminal codes on which they comment posit four distinct forms of criminal culpability: purpose, knowledge, recklessness, and negligence. Negligence as a form of criminal culpability is somewhat controversial, ${ }^{2}$ but the other three are not. What controversy there is concerns how the lines between them should be drawn ${ }^{3}$ and whether there should be additional forms of criminal culpability besides these four. ${ }^{4}$

My purpose in this Essay is to make the case for fewer, not more, forms of criminal culpability. Indeed, I shall try to demonstrate that purpose and knowledge can be reduced to recklessness because, like recklessness, they exhibit the basic moral vice of insufficient concern for the interests of others. I shall also argue that additional forms of criminal culpability are either unnecessary, because they too can be subsumed within recklessness as insufficient concern, or undesirable, because they punish a character trait or disposition rather than an occurrent mental state.

Copyright $\odot 2000$ California Law Review, Inc. California Law Review, Incorporated (CLR) is a California nonprofit corporation. CLR and the authors are solely responsible for the content of their publications.

$\dagger \quad$ Warren Distinguished Professor of Law, University of San Diego. I wish to thank all the participants at the Symposium on The Morality of Criminal Law and its honoree, Sandy Kadish, for their comments and criticisms, particularly Leo Katz and Stephen Morse, who gave me comments prior to the event, and Joshua Dressler, whose formal Response was generous, thoughtful, incisive, and prompt. I also want to thank my colleague Kevin Cole, who also gave me comments prior to the Symposium. On the remote chance that any errors remain, these people are responsible for not having spotted them.

1. See Model Penal Code $\$ 2.02$ (1985); Joshua Dressler, Understanding Criminal LAW ch. 10 (1995).

2. See, e.g., Larry Alexander, Reconsidering the Relationship Among Voluntary Acts, Strict Liability, and Negligence in Criminal Law, 7 Soc. PHIL. \& PoL'y 84 (1990); Jerome Hall, Negligent Behavior Should Be Excluded from Penal Liability, 63 CoLum. L. Rev. 632 (1963); see also authorities cited infra notes 55, 57, and 59.

3. See, e.g., Michael S. Moore, Intentions and Mens Rea, in IssuEs IN CONTEMPORARY LEGAL PhILOSOPHY 245 (R. Gavison ed., 1987) (chronicling the debate over "oblique intention").

4. See, e.g., Alan C. Michaels, Acceptance: The Missing Mental State, 71 S. CAL. L. REv. 953 (1998); Kenneth W. Simons, Rethinking Mental States, 72 B.U. L. REv. 463 (1992). 
Finally, I shall argue that negligence cannot be subsumed within the single form of criminal culpability that can encompass all the other forms, but that is because negligence does not reliably track the moral vice of insufficient concern that all the other legitimate forms of criminal culpability display. ${ }^{5}$ Although one who is negligent on a particular occasion may in fact be one who would act recklessly when given the opportunity, only when he does act recklessly can we deem him to have acted culpably.

With respect to this last point, however, let me be clear: Although I continue to argue that neghigence be dropped as a form of criminal culpability, that issue is not the focus of this Essay. Rather, my purpose here is to argue that purpose and knowledge can be reduced to forms of recklessness, and that, leaving negligence to one side, no form of criminal culpability other than recklessness is necessary or desirable.

My plan of attack is as follows: In Part I, I describe recklessness as a form of criminal culpability and then address some interesting features of its standard formulation. I first point out that although recklessness is generally described as acting with conscious disregard of a substantial and unjustifiable risk (of harm to a potential victim or victimis), ${ }^{6}$ it is the unjustifiability of the risk, not its substantiality, that sliould and probably does do all the work. I then turn to the question of whether one acts recklessly or only attempts to act recklessly if lie incorrectly believes a risk to be more substantial than it actually is. Finally, I consider and reject Ken Simons's proposal to amend the formulation of recklessness. ${ }^{7}$

Having set forth and somewliat reshaped the contours of recklessness, I turn in Part II to the task of demonstrating how the culpable mental states of knowledge and purpose can be folded into recklessness as I have reshaped it. The resulting unified form of criminal culpability is not only theoretically elegant, but it also lias practical advantages over the current tripartite division of purpose, knowledge, and recklessness. Such advantages include its ability to handle the variety of "wilful blindness" cases and to avoid the straitjacket of deeming all cases of purpose with respect to a given harm to be more culpable than all cases of recklessness with respect to the same harm.

In Part III, I turn to some difficulties with the unified approach I have proposed. Complicity, solicitation, and conspiracy typically require a mens rea of purpose regarding the conduct aided, solicited, or agreed upon. ${ }^{8}$ I argue that recklessness can replace purpose for these forms of criminality without creating huge difficulties. With respect to incomplete attempts, which also require purpose, and which cannot be deemed reckless, I urge

5. See Alexander, supra note 2; infra Part III.C.

6. See Model Penal Code $\S 2.02(2)(\mathrm{c})$.

7. See Simons, supra note 4.

8. See Model Penal Code $\$ \S 2.06(3), 5.02(1), 5.03(1)$. 
that they be eliminated as crimes. ${ }^{9}$ Finally, I reprise arguments I have made elsewhere that negligence should be dropped as a form of criminal culpability. ${ }^{10}$

\section{I}

\section{RECKLESSNESS AND ITS PROBLEMS}

The Model Penal Code describes criminal recklessness as follows: "A person acts recklessly with respect to a inaterial eleinent of an offense when he consciously disregards a substantial and unjustifiable risk that the material eleinent exists or will result froin his conduct." formulation is substantially the same as the formulations of recklessness in federal and state criminal codes and judicial decisions. ${ }^{12}$ As I shall explain below, however, this formulation is misleading in one important respect and ambiguous in another.

\section{A. The Dependence of the Substantiality of Risk on Its Unjustifiability}

The standard formulation of recklessness inakes it appear that a defendant, to be deeined reckless, inust consciously disregard a risk that satisfies two independent criteria: (1) the risk inust be "substantial"; and (2) the risk must be "unjustifiable." I believe that this appearance is mistaken both with respect to the purpose behind the formulation and with respect to a normatively attractive conception of the culpability displayed through recklessness.

Consider the following cases:

(1) Driver is accompamied by Passenger, who suddenly displays the symptoms of a severe heart attack. Driver speeds down city streets in order to get Passenger to a hospital in time to save his life. In doing so, Driver creates risks to bystanders' lives, limbs, and property of magnitude $R$.

(2) Daniel loves to set off dynamite on city streets just for the thrill of it. In doing so, he creates risks to bystanders' lives, limbs, and property of inagnitude $R / 100$.

(3) Deborah likes to take Sunday drives. Although she is a very careful driver, in taking Sunday drives she creates risks to bystanders' lives, limbs, and property of magnitude $R / 10,000$.

9. See also Larry Alexander \& Kimberly D. Kessler, Mens Rea and Inchoate Crimes, $87 \mathrm{~J}$. Crim. L. \& Criminology 1138 (1997).

10. See Alexander, supra note 2.

11. Model Penal Code $\$ 2.02(2)$ (c).

12. See U.S. Sentencing Guidelines Manual $\$ 2 A 1.4 \mathrm{cmt} 1$ (1998); ARIZ. Rev. Stat. ANN. § 13-105(9)(c) (Vest 1998); Cal. Penal Code $\S 450(f)$ (1998); N.Y. Penal LaW $\S 15.05(3)$ (McKinney 1999); In re Steven S., 31 Cal. Rptr. 644, 652 (1994); DressLer, supra note 1, at 116. 
(4) Demented likes to expose others to risk. He has concocted his own version of Russian roulette in which, when he pulls a switch, he creates a risk of magnitude $R / 100,000$ that an innocent person will die or be severely injured. ${ }^{13}$

Now if the substantiality criterion is truly independent of the justifiability criterion, then there must be some level of risk imposition below which the actor cannot be reckless. Suppose that level is just above R/100. In Case 1, Driver does satisfy the substantiality criterion but may escape the judgment of recklessness by failing to satisfy the justification criterion. In other words, Driver may have justifiably imposed risk $\mathrm{R}$ on bystanders because his purpose in doing so was to save the life of Passenger. Deborah, the Sunday driver in Case 3, also escapes the judgment of recklessness, in this case because $\mathrm{R} / 10,000$ is below the risk threshold.

The problem with the independent criteria approach, however, surfaces with Cases 2 and 4. Both Daniel and Demented have imposed risks that by hypothesis fail the substantiality criterion, yet the intuition is virtually unshakable that they are being culpably reckless toward bystanders. This is perhaps clearer in the case of Demented, who subjects others to risk simply because he enjoys it. Imposing Russian roulette on others, no matter how high the ratio of empty to loaded chambers, seems a clear case of criminally culpable conduct. ${ }^{14}$ What is doing all the work here is, of course, the justifiability criterion, which also explains the intuition about Daniel, namely, that the mere thrill of a dynamite blast does not justify imposing more than a de minimis risk on others.

What emerges from consideration of these cases is the proposition that the level of risk that one may permissibly impose on others is dependent on the reasons one has for imposing that risk. The reason Driver has for imposing risks on bystanders is a weightier one than the reason Deborah, the Sunday driver, has for doing so. Thus, we deem it perımissible for Driver to impose a higher risk on bystanders than Deborah may impose. Daniel's reason-the thrill of explosions-may justify even less riskimposition than Deborah is permitted. And Demented's reason-imposing risks on others for its own sake-cannot justify even the slightest increase in risk.

The conclusion that one should draw from these examples is that recklessness consists of imposing unjustifiable risks on others. The level of risk imposed will bear on its justifiability but is not itself an independent criterion of recklessness. Even very tiny risk-impositions can be reckless if

13. See Larry Alexander, Are Procedural Rights Derivative Substantive Rights?, 17 L. \& PHIL. 19, 20 (1998); David McCarthy, Rights, Explanation, and Risks, 107 ETH1cs 205, 211 (1997).

14. See McCarthy, supra note 13. 
imposed for insufficient or misanthropic reasons, just as very large riskimpositions can be nonculpable if supported by weighty reasons. ${ }^{15}$

If recklessness consists of imposing unjustifiable risks on others, then it can be characterized as displaying the central moral vice of insufficient concern. It is my contention in this Essay that all recognized forms of criminal mens rea other than negligence display this single moral vice, and that they do so in ways that establish their unity rather than their separateness.

\section{B. Does Recklessness Require "Objective" Risk?}

Consider the following case: David wants to get home in time to watch the Lakers game on television. He accelerates until his speedometer reads ninety miles per hour, a speed that he believes creates a very substantial risk of death, serious bodily injury, or property damage to other drivers, passengers, and pedestrians. In fact, his speedometer is broken, and he is only gonig fifty-five miles per hour, a reasonable speed given the road and traffic conditions. Is David acting recklessly?

There are two approaches one might take to this case. One might say that David is not acting recklessly because the actual risk he is imposing is reasonable, even given his fairly unimportant reason for miposing that risk. In other words, on this view, recklessness requires that an actor actually impose an unjustifiable risk, and it is not sufficient that he merely believes he is imposing a risk that would be unjustifiable were it to exist. David is culpable in that he is attempting to act recklessly, but he is not reckless.

Let us call this approach the objective approach. Essentially, under the objective approach, one is reckless when one adverts to an actual risk of a magnitude that would render one negligent if imposed inadvertently. If one believes a risk exists that would render one negligent if imposed inadvertently, but the actual risk is below that level, then one has attempted but failed to act recklessly.

The other approach is the subjective one: An actor is reckless if he believes he is inuposing a level of risk that would be unjustifiable regardless of the actual risk he is imposing. On this approach, David is driving recklessly at fifty-five imiles per hour based on his belief that he is driving ninety miles per hour.

For one who shares my belief that attempts and successes should be regarded not only as equally culpable, but also as equally blameworthy and punishable, it ultimately matters little whether the objective or the subjective approach to recklessness is chosen. On either approach, David is equally culpable, and therefore equally blameworthy and punishable.

15. For a discussion of the complex morality of risk-imposition, see Kenneth W. Simons, Negligence, 16 Soc. PHIL. \& POL'Y 52 (1999). 
Nonetheless, I believe the correct approach is the subjective one because it avoids the troubling notion of an objective risk. Risk is an essentially epistemic concept. Risk is always relative to someone's perspective, a perspective that is defined by possession of certain information but not other information. For God-who possesses complete information about everything - risk does not exist. For God, all events have a probability of either one or zero.

The objective approach to recklessness requires us to be able to assign a risk to an activity that is different from both whatever risk the actor perceives and the risk God perceives (one or zero). Thus, this approach requires that we construct an artificial perspective containing some but not all mformation. There are obviously an indefinite number of such possible perspectives, each one generating a different risk. I maintain that there is no nonarbitrary way for us to construct such a perspective. Nor, if we are not bothered by treating "attempted recklessness" the same as recklessness, is there any motivation for us to construct such a perspective.

Imagine that in our hypothetical case, David, actually driving fiftyfive but believing that he is going ninety, hits and kills a child who darts out in the road. If David had been driving more slowly, he could have averted the tragedy. It turns out then that the actual risk of death he was imposing had a probability of one, which is even higher than the unjustifiable risk he thought he was imposing. Of course, someone who knew David's actual speed but who, like David, was unaware of the presence and movements of the child, would not have deemed David's speed to be an unjustifiable risk-imposition. But why should we privilege that hypothetical perspective over either David's perspective or the perspective of someone aware of the child?

My quarrel with the notion of objective risk, and the reason I favor the subjective approach, is part of my quarrel with negligence as a form of criminal culpability. ${ }^{16}$ I should point out that not only is the law against me on the issue of negligence, but it also appears to be against me on the issue of objective versus subjective approach to recklessness. ${ }^{17}$ As I have said, the latter issue is only of practical importance if attempts are punished less severely than successes. Nevertheless, even if attempts and successes were equated, I think it is important to expunge from the law the notion of objective risk, and with it the objective approach to recklessness. That

16. See Larry Alexander, Crime and Culpability, 5 J. Contemp. Legal Issues 1, 17-20 (1994); Alexander, supra note 2, at 98-103.

17. The Model Penal Code's formulation of recklessness as a form of criminal liability is consistent with either the objective or the subjective approach. See supra notes 11-12 and accompanying text. However, one important commentator assumes that the Code adopts the objective approach. See Paul H. Robinson, Competing Theories of Justification: Deeds v. Reasons, in HARM AND Culpability 45, 57-58 (A.P. Simester \& A.T.H. Smith eds., 1996). 
done, the distinction between recklessness and attempted recklessness would be completely effaced.

\section{Recklessness as Callousness}

Recently, Ken Simons has proposed "rethinking" the traditional criminal mental states of purpose, knowledge, recklessness, and negligence, and adding a new one to the existing four. ${ }^{18}$ Simons divides criminally culpable mental states into two categories: states of belief and states of desire. In the former he places knowledge, recklessness, and negligent ignorance or mistake. In the latter he places purpose. According to Simons, this division omits recklessness as callousness or indifference, which Simons places under states of desire as a lesser form of culpability than purpose. Thus, Simons ends up proposing five criminal mental states, namely, the traditional four plus the desire-state form of recklessness.

Simons's crucial assumption is that traditional recklessness is culpable solely because of the cogmitive state of the actor and not because of the conative state it reflects. He therefore proposes a second form of recklessness to cover culpability based on conative vices, such as callousness or indifference toward others' interests. But Simons's assumption is incorrect, and his proposal is either unnecessary-because it is already covered by recklessness-or troubling.

As I argued in the previous section, recklessness turns on whether it is unjustifiable for the actor to impose the risk on others he perceives to be present. The justifiability of his taking that risk is in turn a function of (1) the level of risk he perceives and (2) the reasons he has for taking that risk. Actors who impose risks on others that are not justified by their reasons are aptly characterized as "callous" or "indifferent," but that characterization is merely another way of saying that they have acted recklessly. There is no culpability lacuna that recklessness qua callousness or indifference is needed to fill.

Simons argues that the categories of belief-states and desire-states are independent of one another, and that there is a hierarchy of culpable beliefstates and a separate hierarchy of culpable desire-states. ${ }^{19}$ But this is quite misleading. As I have shown, recklessness is a function of both belief (in the level of risk) and desire (reasons for acting). And in Part Two, I shall argue that purpose and knowledge are included within recklessness. No act is culpable solely because of the belief-state of the actor, nor is any act culpable solely because of the actor's desire-state.

Simons's view that desire-states can be culpable apart from beliefstates suggests a troubling, as opposed to redundant, interpretation of his proposal. There is some evidence in his article that Simons would punish

18. See Simons, supra note 4 .

19. See id. at 477. 
an actor solely for acting with a callous or indifferent attitude towards others' interests. ${ }^{20}$ Suppose, for example, that Deborah is engaging in her Sunday driving within the speed limit and believes she is creating a low level of risk to others. And suppose that the pleasures of Sunday driving are sufficient to justify imposing that low level of risk on others. But suppose also that Deborah is callous towards the risks she imposes on others, and that even if she were to come to believe that the risks imposed by her Sunday driving were much higher than sle actually believes them to be, she would continue to drive notwithstanding that belief. On my account and the law's, Deborah is not acting recklessly at this moment and is therefore not culpable. She has an undesirable character trait, one that might dispose her to act recklessly if the circumstances were right, but her counterfactual culpability does not translate into present culpability.

Does Simons believe that because of her callousness, Deborah is now acting culpably, even though the risk level she perceives is justified by her reason for acting? Expanding criminal liability to include callous Deborah would convert criminal liability from being act-focused to being characterfocused. Deborah has not acted wrongly; rather, she has a character trait that at most makes her a counterfactual wrongdoer.

I doubt that Simons intends for us to punish callous Deborah. Indeed, I prefer to read Simons's proposal to focus more attention on desire-states as consistent with my contention that the justifiability criterion for recklessness is dominant, and that the level of risk-imposition permitted is a function of the actor's reasons for acting. Thus interpreted, Simons's argument can be turned, not into a brief for more culpable mental states, but rather into a brief for a single conception of criminal culpability.

\section{II}

A UNified Theory of CRIMINAL CUlpability: ReCKLESSNESS AS Comprehending KNowledge, Purpose, and Wilful Blindness

Morality enjoins us to be concerned with others' interests. On some views, such as utilitarianism, that injunction is quite demanding. On other views, sucli as libertarianism, it is less so. But on all views, we are enjoined at a minimum not to inflict certain harms on others.

From the basic moral injunction to have due regard for others' interests, we can derive injunctions for how to act in situations of epistemic uncertainty, situations in which we do not know for certain how our acts will affect others. One basic injunction is that we should not choose an act in order to bring about harms (of certain types) to others, unless, that is, certain greater interests (of ours or of third parties) require such harms to

20. The evidence is Simons's insistence that recklessness as callousness be viewed as separate from recklessness as acting in the face of a perceived substantial risk of harm. 
others. In other words, we are enjoined ceteris paribus not to act with the conscious object of harming others.

A second basic inoral injunction is that we not choose an act that creates what we believe is a risk of harm to others, again unless that act is required to vindicate the greater interests of ours or third parties. Because it is inpossible to act at all without creating risks of harms of various degrees and kinds, this injunction boils down to an injunction to impose only justifiable risks on others. These two moral injunctions can be easily consolidated into a single one if we deem trying to bring about harm to others as presumptively making any risk imposed on others an unjustifiable one. We end up with a single inoral injunction for how to choose when one is uncertain about the consequences his acts will cause: choose only those acts for which the risks to others' interests-as you estimate those risksare sufficiently low to be outweighed by the interests, to yourself and others, that you are attempting to advance (discounted by the probability of advancing those interests). ${ }^{21}$

This single moral injunction can serve as the basis for a unified conception of criminal culpability. In other words, all cases of criminal culpability represent failures to comply with this injunction. Because, as I have shown, recklessness consists of imposing risks on others not justified by the actor's reasons-no matter the level of the risks-recklessness fits squarely within this moral injunction. In this Part, I shall show how two of the remaining forms of criminal culpability, knowledge and purpose, fit within the same injunction. Indeed, I shall argue that the single moral injunction is no more than an injunction against criminal recklessness, and that knowingly harming others and acting for the purpose of harming others are forms of criminal recklessness.

Another way of thinking about the ways in which knowledge and purpose fit within a conception of recklessness is to visualize recklessness as an area on a graph, where risk is the $\mathrm{x}$-axis and justification is the y-axis. As I shall explain below, knowledge is the limiting case of recklessness on the risk axis; purpose is the limiting case of recklessness on the justification axis.

\section{A. Knowledge}

A person acts with criminal "knowledge" with regard to an element of a crime when he believes to a practical certainty that his conduct is of a particular nature, that an attendant circuinstance exists, or that his conduct will bring about a particular result. ${ }^{22}$ Unlike recklessness, which focuses on

21. The parenthetical phrase is necessary because imposing even a moderate risk of harm on others cannot be justified by even very compelling interests of the actor or third parties if the chance of the act's succeeding in advancing those interests is quite remote.

22. See Model Penal CODE $\S 2.02(2)(b)$ (1985). 
both the risk imposed and the actor's justification for imposing it, at first glance knowledge appears to focus only on risk.

One might think from a superficial comparison between the formulation of knowledge and the formulation of recklessness that when an actor is practically certain that his act will be harmful to others, he is forbidden from undertaking it regardless of his reasons for doing so, whereas if he believes the risk is less than that of practical certainty, he may act if his reasons are sufficiently weighty. But it is not the case that knowingly imposing harm is always unjustified. For example, one may justifiably impose a practical certainty of harm on another to defend oneself or others, or in some cases where worse harm to another or a similar harm to many others can only be averted thereby. ${ }^{23}$

"Knowledge"-acting with the belief that it is practically certain that one's act will be harmful to others-is merely a limiting case of recklessness along the axis of degree of perceived risk of harm. The other recklessness axis, the axis of the actor's reasons, remains fully operative. The only real distinction between knowledge and recklessness in the criminal law is that at some point as the risk of harm approaches a practical certainty, the burden of proof (or production) ${ }^{24}$ on the issue of whether the defendant's reasons for acting justified the risk of harm he created shifts from the prosecution to the defendant. That shift in the burden of proof (or production) makes sense both in terms of the probability that the act is or is not justified and the relative access to the justifying circumstances, if any. But the difference in the allocation of burdens does not reflect any substantive distinction between knowledge and recklessness.

Seeing knowledge as just a species of recklessness enables us to avoid two errors. First, it allows us to avoid the error of deeming all cases of knowledge to be more culpable than all cases of recklessness, even where the harm risked is the same. For example, someone who imposes a very high risk of harm on another-a risk just short of practical certainty-for a very frivolous reason, such as a thrill, is surely more culpable than one who imposes a practically certain harm for a quite weighty, but ultimately insufficient, reason. For example, if I knowingly inflict severe bodily injury on another to prevent him from accidentally destroying my entire life's work, I may be culpable; but I am surely less culpable than if I impose a slightly lower risk of the same harm on him just to satisfy my urge to drive like a madman.

23. See, e.g., id. $\$ \$ 3.02,3.04,3.05$.

24. The Model Penal Code regards (the absence of) justification as part of the prosecutor's burden of proof. See id. $\S 1.12(2)$. In most jurisdictions, the defendant has the burden of proving the justifying facts. See, e.g., Commonwealth v. Markum, 541 A.2d 347 (Pa. Super. Ct. 1988); Commonwealth v. T.J.J.R., Inc., 548 A.2d 390 (Pa. Cmmw. Ct. 1988). 
The second error averted by seeing knowledge as just a species of recklessness is the misclassification of cases of wilful blindness. A typical such case is one where the defendant is asked by someone at an airport in a drug-producing country to carry a package on the plane and give it to a specific person when he arrives in the United States. Where the applicable statute punishes only "knowing" drug smuggling, courts have struggled to find the defendant-whom they rightly regard as culpable-guilty by deeming his wilful blindness to be tantamount to knowledge. ${ }^{25}$ Yet wilful blindness is not knowledge; it is an attempt to avoid knowledge, and it frequently achieves that goal in that defendants who engage in wilful blindness do not believe to a practical certainty that their conduct is harmful.

The prototypical wilfully blind defendant is, of course, reckless. The risk he is taking of, say, smuggling drugs is an unjustifiable one. The unjustifiability of the risk cannot, however, convert his recklessness into knowledge without absurd results. For example, suppose a drug smuggler employs 100 "mules" to do his smuggling. ${ }^{26}$ His modus operandi is to give each mule a suitcase to carry into the target country. In ninety-nine of the suitcases he places only innocent items, such as clothes. In one he places drugs. The mules are not told which suitcase holds the drugs, and they do not open the suitcases. In such a situation, it would be absurd to deem the mule with the drugs to have "knowingly" smuggled them. What he has done is take a one in a hundred chance of smuggling drugs for no legally sufficient reason. ${ }^{27}$ If a similar risk-imposition would not be deemed "knowing" if undertaken for good reasons-say, for example, you are visiting a foreign country and a person whom you greatly admire asks you to carry a gift to a friend in the United States, and you entertam the thought that there is a tiny but real chance that the person you admire is a drug smuggler - then it is misguided to deem the risk-imposition "knowing" inerely because one disapproves of the reasons for undertaking it.

In some sense, all risk-imposition is wilful blindness in that the actor could always seek inore information about the risk before acting, although the act thereafter undertaken would be different temporally and circumstantially froin the act undertaken without gathering more information.

25. See, e.g., Mattingly v. United States, 924 F.2d 785, 792 (8th Cir. 1991) ("[T] knowledge may be inferred from deliberate acts amounting to willful blindness...."); State v. LaFreniere, 481 N.W.2d 412 (Neb. 1992); see also United States v. Whittington, 26 F.3d 456 (4th Cir. 1994); United States v. Mancuso, 42 F.3d 836 (4th Cir. 1994); United States v. Jewell, 532 F.2d 697 (9th Cir. 1976); United States v. Incorporated Village of Island Park, 888 F. Supp. 419 (E.D.N.Y. 1995).

26. This example is, I discovered, very similar to one used elsewhere by Douglas Husak and Craig Callendcr. See Douglas N. Husak \& Craig A. Callender, Wilful Ignorance, Knowledge, and the "Equal Culpability" Thesis: A Study of the Deeper Significance of the Principle of Legality, 1994 WIs. L. REv. $29,37$.

27. Note how this example ties into the earlier argument that the actor's reasons can render taking even small risks "reckless." See infra Part II.A. 
Moreover, in ordinary recklessness cases, when we assess the actor's reasons for imposing the risk, we are also implicitly assessing his reasons for not investigating the danger further. Viewing recklessness as the allencompassing conception of criminal culpability, rather than as different from and less culpable than knowledge, allows us to evaluate correctly the wilful blindness cases and does not tempt us to distort them into cases of knowledge. ${ }^{28}$

\section{B. Purpose}

A person acts with criminal purpose with respect to the conduct or result elements of an offense if "it is his conscious object to engage in conduct of [the required] ... nature or to cause [the required] . . . result."29 Unlike knowledge, which at first glance appears to focus only on the actor's assessment of the risk of harm, purpose at first glance appears to focus only on the actor's desires regarding the possibility that his conduct will prove harmful, while ignoring his beliefs about this possibility. But as with knowledge, this initial appearance proves to be misleading.

The crucial point is that in order to act with criminal purpose, the actor must believe that his conduct increases the risk of harm, even if the increase is very slight. Consider the Jackal, who fires a shot at deGaulle from the Eiffel Tower believing his chance of success to be one in a million. If he does succeed, he will have shot deGaulle "purposely," given that it is his "conscious object" in shooting that deGaulle be killed (that is how he collects liis assassin's reward). But characterizing this act as purposeful assumes that the Jackal believes that although firing the gun produces only a one in a million chance of killing deGaulle, firing the gun does increase the probability of deGaulle's being killed over the probability of deGaulle's being killed if the Jackal refrains from firing the gun. If the Jackal does not believe his firing the gun increases the probability of killing deGaulle-if he believes deGaulle has no worse chance of surviving if he fires the gun than if he does not-then were the shot to kill deGaulle, it would not be a purposeful killing. For in such a case, the Jackal would not have fired the gun for the purpose of killing, given that he did not believe firing the gun produced any increased chance of killing deGaulle.

If, in order for an act to be criminally purposeful, the actor must believe that he is increasing to some extent the risk of harm, then criminal purpose has the same structure as recklessness. It has an axis for the actor's

28. Recklessness, because it is sensitive to both risks and reasons, allows us to distinguish between those whom David Luban calls ostriches, who merely do not want to know, and those whom he calls foxes, who contrive deniability. See David Luban, Contrived Ignorance, 87 GEo. L.J. 957, 96875 (1999). Ostriches and foxes may take the same risks, but they have different reasons for doing so. Both may be culpably reckless, but foxes are more culpable than ostriches given the same level of risk and the same harm.

29. Model Penal Code $\$ 2.02(2)$ (a)(i). 
belief in risk and an axis for the actor's reasons for imposing it, the latter in the case of purpose being the actor's desire to bring about the prohibited result or conduct. And as with knowledge, the possibility of justification is not eliminated but rather the burden of proof (or production) is shifted to the defendant. In other words, just as knowledge can be viewed as a special case of recklessness, in which the defendant's belief regarding risk (that it is very high) creates a presumption of sorts that his reasons are inadequate to justify his conduct, so too can purpose be viewed as a special case of recklessness, in which the defendant's reason is presumptively unjustifying.

I say that the conscious object to engage in harmful conduct or produce harmful results is only presumptively unjustifying because there are cases in which purposeful criminal conduct can be justified. Having harm to others as one's conscious object is not the same thing as having that harm be one's ultimate object. Nor is it the same thing as appropriating others' bodies, talents, or labor, soinething soine deontologists might claim can never be justified. ${ }^{30}$ Thus, for example, it might be iny conscious object to wound a houmicidal maniac who otherwise will kill an innocent party. My wounding him sufficiently to foil his attack will be a purposeful battery. Nonetheless, I nay be acting justifiably in defending others against his attack.

Or consider the case of the trapped spelunceans. ${ }^{31}$ Suppose that they kill one of their party because they calculate that his continued breathing will deprive the rest of the oxygen they need to survive until the rescue party can reach them. Whether or not they are ultimately deemed to have been justified in killing the one inember, they have not "appropriated" him to benefit theinselves. Rather, they have merely prevented him froin harming them. ${ }^{32}$

If purposeful criminal conduct is not always unjustified, neither is it always more culpable than knowledge or recklessness. One may well believe that the spelunceans lack a justification for hoinicide without believing they are more culpable than those who impose high risks of death on others for the inere thrill of it but who do not have others' deaths as their conscious object. One inay also conclude that a purposeful criminal actor who inposes a very tiny risk-for example, iny hypothetical Jackal-is less culpable than a nonpurposeful actor who inposes huge risks for weak reasons. Thus, as we saw for knowledge, a unified

30. See Larry Alexander, Is Morality Like the Tax Code?, 95 Mrch. L. REv. 1839, 1845-47 (1997).

31. See Lon L. Fuller, The Case of the Speluncean Explorers, 62 HaRv. L. REv. 616 (1949).

32. Compare Regina v. Dudley and Stephens, 14 Q.B.D. 273 (1884) (sailors appropriated a cabin boy's flesh for food), with United States v. Holmes, 26 F. Cas. 360 (C.C.E.D. Pa. 1842) (No. 15,383) (sailors threw overboard lifeboat passengers threatening to capsize the boat). 
conception of criminal culpability may actually avoid the potential problems that arise within the existing category of purpose.

\section{III}

\section{Problem CASES for the Unified Conception}

\section{A. Complicity}

To be deemed complicit in a crime, most criminal codes require that one have aided, attempted to aid, or encouraged the crime with the purpose that the crime be committed. ${ }^{33}$ It is not enough to suspect that the person aided or encouraged will commit the crime, or even to be practically certain that the person aided or encouraged will do so. To be deemed a criminal accomplice, one must have the conscious object that the person aided or encouraged commit the crime.

The drafters of the Model Penal Code, in requiring purpose for complicity, recogmized that such a standard would be controversial. However, they were afraid that allowing knowledge, much less recklessness, to suffice for complicity would create severe difficulties, particularly for merchants. ${ }^{34}$ Suppose, for example, the owner of a hardware store strongly suspects that the purchaser of a crowbar intends to use it in a burglary. If knowledge or recklessness sufficed for complicity, the owner would fear possible criminal liability if he allowed the sale. On the other hand, if he did not allow the sale, and he turned out to be mistaken about the purchaser, he would face embarrassment and possible liability. And interrogating the purchaser would hardly be better than just denying the sale outright. Therefore, to avoid placing merchants in this dilemma, the Code retained the common law requirement of purpose for complicity.

Moreover, there is a broader policy concern beyond freeing the merchants from this dilemma. If knowledge or recklessness were sufficient for accomplice liability, people's actions would be burdened "with doubts and worries about what someone else might culpably do as a consequence... [, which] would tend to create an undesirable insecurity in the conduct of ordinary affairs." 35

I believe that a umified mens rea of recklessness-insufficient concern-is capable of serving as the mens rea for complicity. To show this 1 shall first argue that the purpose requirement fails to criminalize too many instances of conduct that should be criminalized (and probably are

33. See, e.g., Model Penal Code \$§ 2.06, 5.02; People v. Beeman, 674 P.2d 1318 (Cal. 1984). Note that some states have a form of criminal complicity called criminal facilitation that requires only knowledge. See, e.g., ARIz. Rev. STAT. ANN. § 13-1004 (West 1989); KY. REv. STAT. ANN. § 506.080 (Michie 1990); N.D. CENT. Code § 12.1-06-02 (1997);N.Y. Penal LaW § 115 (McKinney 1998); United States v. Fountain, 768 F.2d 790 (7th Cir. 1985).

34. See Model Penal Code $\$ 2.06$ emt. 6(c).

35. Sanford H. Kadish, Reckless Complicity, 87 J. Crim. L. \& Criminology 369, 371 (1997). 
criminalized, despite the formal requirement of purpose). I shall then describe how a unified conception of criminal culpability can address the concerns that led the drafters of the Model Penal Code to retain the purpose requirement.

Here is a scenario that is probably not unusual. Godfather announces to Soldier that Godfather wants to whack Vinnie, who has insulted him, and that Godfather wants Soldier to bring him a gun with a silencer. Soldier brings Godfather such a gun, and Godfather uses it to kill Vinnie. Soldier is tried for complicity in the murder.

Suppose that at his trial, Soldier testifies, and the jury believes him, that he did not care whether Godfather killed Vinnie with the gun, although he was pretty sure that Godfather would do so. Indeed, suppose Soldier testifies, and the jury believes him, that he liked Vinnie and hoped that Godfather would not kill him. Soldier's sole motive in complying with Godfather's request was loyalty to Godfather, not any desire that Vinnie be killed. Should the jury acquit Soldier? According to the law, the answer is "yes." Soldier lacked purpose, and purpose is required for conviction.

But should Soldier be off the hook? Here, I believe, most would answer "no." Moreover, regardless of the law's formal requirement of purpose, I suspect that most juries and even judges would deem Soldier to be an accomplice in Vinnie's murder. To find otherwise would open the door to vast numbers of those who assist the commission of crimes to argue, often credibly, that they assisted for reasons other than their desire to see the crime committed.

Indeed, Soldier should be criminally liable even if he was not certain that Godfather would kill Vinnie but only thought there was a sufficient probability of that outcome. ${ }^{36}$ For example, consider the case of Mule, who, solely out of friendship to Cartagena Carl, agrees to pick up a suitcase Carl has shipped into the United States, knowing that such suitcases frequently contain drugs. Mule is acting recklessly with respect to aiding drug smuggling - not knowingly or purposely_but we may well believe that Mule should be deemed an accomplice in drug smuggling.

Or consider an example provided by Sanford Kadish. ${ }^{37}$ Defendant reveals the combination of his employer's safe to someone he knows to be a career burglar. He does so because he is bedridden and needs some papers from the employer's safe. He realizes that there is a very high risk that the burglar will steal the employer's cash, but he believes that his need for the papers is worth that risk. Of course, he fervently hopes that the cash

36. The level of probability estimated by Soldier, to be sufficient for complicity purposes, should be that at which the risk to Vinnie outweighs whatever value attaches to Soldier's loyalty to Godfather-probably a very low level of risk.

37. See Kadisb, supra note 35, at 371. 
will be left untouched. If the burglar does steal the cash, defendant is not an accomplice in the burglary under the law as it stands. ${ }^{38}$

Some commentators have argued that the basis of criminal liability for complicity is that criminal associations increase the risk that successful crimes will occur. In the words of Daniel Yeager, an accomplice is guilty of a crime not because he necessarily causes the crime to occur, but because he is "an excessive risk-taker" with respect to the crime's occurring. ${ }^{39}$

It is but a short step from Yeager's position that aiding crimes is a form of risk-taking to my position that the mens rea for complicity should be recklessness rather than purpose. Although, as I have argued, purpose is a form of recklessness, recklessness includes more than acting with harm as one's conscious object. And complicity should not be limited to those who assist with harm as their conscious object; rather, it should extend to all whose assistance involves risk imposition that is excessive relative to their reasons for so acting.

Indeed, Kadish points out that recklessness has already become the mens rea for complicity in a class of cases, namely, those in which the defendant purposely assists someone else in the commission of one crime, and it is foreseeable that the latter, in committing that crime, will commit some further crimes. ${ }^{40}$ Even if the defendant has no purpose that those further crimes be committed-indeed, even if he lacks the mens rea required for those crimes-if the parties he assists go ahead and commit those further crimes, most jurisdictions deem him to be an accomplice in those crimes. ${ }^{41}$

Kadish, like me, approves of such examples of reckless complicity, except that, again like me, he would deem the defendant guilty only of the crimes for which recklessness is a sufficient mens rea. ${ }^{42}$ Because I would make recklessness the only mens rea for criminal liability, the question for me becomes a simpler one: Did the defendant take an unjustifiable risk that the parties he assisted or encouraged would bring about the specific harm they did? (Indeed, because I would not distinguish between "attempts" and "successes," it would not matter whether the parties assisted committed either the crime the defendant intended or the further

38. Kadish argues against this result. He also provides additional examples of cases where recklessness should suffice for complicity. See id. at 386-87.

39. Daniel Yeager, Helping, Doing, and the Grammar of Complicity, 15 CRIM. JUsT. ETHICs 25 , 31 (1996).

40. See Kadish, supra note 35, at 373-78.

41. See id. at 375-76. Kadish also points out that recklessness or less as to circumstances-for example, a girl's age in a statutory rape prosecution-is sufficient for aecomplice liability. See id. at 285-86.

42. See id. at $378-79$. 
crimes the defendant foresaw; all that would matter is what harms the defendant unjustifiably risked.) $)^{43}$

What about the concerns for merchants that led the drafters of the Model Penal Code to adopt the more restrictive mens rea of purpose for complicity? I believe that a provision that exculpates all merchants who sell at the market price or who offer services at their customary rate should alleviate the merchant's dilemma. No matter how suspicious a merchant is of a customer's intentions, he may deal with the customer with no fear of prosecution so long as he does not discriminate in the customer's favor, say, by "selling" him a $\$ 300$ gun for 10 cents. This safe harbor for merchants, however, is not so large that Soldier and Mule can avail themselves of it, unlike the existing restriction to purpose.

A second kind of safe harbor can be created for persons who are not merchants but whose "aid," even when accompanied by awareness of the criminal propensities of the one aided, should not rise to the level of recklessness. Consider Kadish's example of someone who knows that another intends to commit arson but who helps the arsomist fix his car's seat belt, or shows him where to wait for a taxi.4 Kadish believes, and I concur, that such cases of everyday, ordinary assistance should not rise to the level of recklessness, perhaps because such assistance is usually so readily available from others, or because in the absence of such assistance, the one aided would probably still proceed with his criminal project.

Finally, Kadish attributes much uneasiness about extending complicity to include reckless assistance to an ethic of mdividualism that makes us responsible for our own acts but not responsible for acts of those whom we may assist or influence but who remain free moral agents. ${ }^{45}$ Even if we can predict another's freely chosen act, we may still feel that such an act is not our responsibility, even if we have facilitated and encouraged it.

This ethic of individualism would be grounds for objecting to reckless complicity. But more miportantly, the objection it raises is not to the recklessness side of the equation. Rather, it is an objection to liability for complicity tout court. For according to this view, even purposeful aid should not implicate one in the criminal choices of another. In the end, then, even those who buy this objection should favor dropping complicity from the criminal law rather than retaining complicity but restricting it to purposeful aiding.

\section{B. Inchoate Crimes}

Attempts typically require a mens rea of purpose regarding either the proscribed conduct or the proscribed result, although the Model Penal

\footnotetext{
43. See Alexander, Crime and Culpability, supra note 16.

44. See Kadish, supra note 35 , at 388 .

45. See id. at 393.
} 
Code allows knowledge regarding results to suffice for result crimes ${ }^{46}$ On the other hand, the Code and most jurisdictions recognize a crime of reckless endangerment that covers conduct that is reckless regarding certain proscribed results. ${ }^{47}$ The latter crime could easily be expanded so that it covers anyone who acts recklessly regarding any proscribed conduct-that is, anyone who takes an unjustifiable risk that he is engaging or will, without further action, engage in proscribed conduct-or anyone who acts recklessly regarding any proscribed result. Such a person would be guilty of what essentially would be an omnibus attempt, with punishment geared to the conduct or result risked, the degree of risk estimated by the actor, and the actor's reasons for taking the risk. Ordinary completed attemptsthose in which the actor takes the last step he believes necessary to engage in proscribed conduct or bring about a proscribed result, and in which the actor has as his conscious object the proscribed conduct or result-would be an included subgroup within this expanded class of reckless "attempts."

What would not fit within this reconceptualization of attempts qua recklessness are incomplete attempts. Incomplete attempts are those in which the actor has taken "substantial steps" toward commission of a crime but has not taken the last step he believes is necessary. ${ }^{48}$ Incomplete attempts require purpose-the purpose to engage in what will be a complete attempt (which, under the law as it presently stands, itself requires purpose regarding proscribed conduct or results). If complete attempts are replaced by recklessness along the lines I suggest, incomplete attempts would consist of taking substantial steps toward acting recklessly with the purpose of acting recklessly. The purpose requirement would have to remain, however, for it makes no sense to deem someone to be recklessly approaching acting recklessly. At any given moment, one is either reckless with respect to proscribed conduct or results, or one is not. If one is not in the act of creating a substantial risk of proscribed conduct or results, then even if one intends to act recklessly in the immediate future, one is not reckless at that particular moment. One's future freely chosen acts are not the kind of thing about which one can now act in a risky way. ${ }^{49}$

Kimberly Kessler and I have elsewhere argued at length for dropping incomplete attempts from the criminal law, ${ }^{50}$ and I shall not repeat those arguments here. I should point out, however, that the implications of our

46. See Model Penal Code $\S 5.01(1)(b)$ (1985). Result crimes are those, such as homicide, in which the conduct, to be criminal, must bring about some further event, such as death.

47. See id. \$211.2 (recklessly endangering another person); id. § 220.2(2) (risking catastrophe); N.Y. Penal LaW § 120.25 (West 1998) (reckless endangerment); Wash. Rev. Code ANN. § 9A.36.050 (West Supp. 1988) (reckless endangerment).

48. See Model Penal Code $\$ 5.01(1)(c)$.

49. Leo Katz raises some interesting possible counter-examples to this claim, however. See LEO Katz, Ill-Gotten Gains: Evasion, Blackmail, Fraud, and Kindred Puzzles of the Law (1996).

50. See Alexander \& Kessler, supra note 9, at 1168-73. 
argument extend beyond the pure substantial step attempt and encompass a whole host of substantive crimes such as burglary that include an incomplete attempt as an element of the offense..$^{51}$ The argument also implies that the crime of conspiracy should be eliminated and replaced in part by the crime of criminal solicitation, expanded along the lines suggested in the previous subsection to include recklessness regarding whether one has encouraged others to commit crimes. ${ }^{52}$

\section{Negligence}

Negligence involves madvertence to a risk that, if adverted to, would render the actor reckless. I have argued elsewhere that negligence as inadvertent risk-taking is not culpable conduct. ${ }^{53} \mathrm{I}$ have further argued that because such negligence is nonculpable, it cannot be defined nonarbitrarily, nor can it be distinguished from cases of strict liability or involuntariness. For these reasons, I have urged that negligence be dropped from criminal codes as a form of criminal culpability.

I have no new arguments to deploy in favor of this conclusion, so I shall sketch the old arguments briefly and leave it to my prior efforts to pull the laboring oar on this point.

\section{The Moral Immateriality of Failure to Advert to Risk}

The world is full of risks to which we are oblivious. Or more accurately, because risk is an epistemic, not ontic, notion, ${ }^{54}$ we frequently believe we are creating a certain level of risk when someone in an epistemically superior position to ours would assess the risk to be higher or lower than we have estimated. Sometimes the epistemically superior position is the product of better information: For example, the doctor knows that what we believe is just a mole is in fact a life-threateming melanoma. At other times we have failed to notice something that another might have noticed, or we have forgotten something that another might have remembered. And once in a while, our lack of information, failure to notice, or forgetfulness results in our underestimating the riskiness of our conduct and causing harm.

We are not morally culpable for taking risks of which we are unaware, or so I contend. At any point in time we are failing to notice a great many things, we have forgotten a great many things, and we are misinformed or uninformed about many things. An injunction to notice, remember, and be fully informed about anything that bears on risks to others is an injunction no human being can comply with, so violating this

51. See id. at 1193.

52. See id. at 1178-81.

53. See Alexander, supra note 2.

54. See supra Part I.B (discussing objective risk). 
injunction reflects no moral defect. Even those most concerned with the well-being of others will violate this injunction constantly.

Of course, inadvertence to risk may reflect moral culpability in the sense that it is the product of a prior reckless act. ${ }^{55}$ I may have failed to take the free course on medical problems of children, realizing at the time that I was taking a substantial risk that I might someday fail to recognize a child's serious medical problem. I may have failed to take the course on Japanese for sailors, realizing at the time that I was taking a substantial risk that I might someday cause harm because of a misunderstanding. ${ }^{56} \mathrm{I}$ inay have failed to write a note to myself to get the brakes fixed, realizing at the time that I was taking a substantial risk of forgetting. Or I may have engaged in a heated discussion with the passenger in my car, realizing at the time the discussion began that I was taking a substantial risk of having my attention diverted from my driving. In all of these examples I might be acting recklessly toward others, and hence culpably, by taking a risk that I would later fail to advert to a risk to others.

Even if inadvertence to risk is sometimes the product of a culpable act, it is still not culpable. It is merely the nonculpable product of some prior culpable act. And most often, inadvertent risk imposition cannot be traced to any prior act that we would deem morally culpable.

I realize that both the criminal law and most people's intuitions run against me on the issue of whether inadvertent negligence is culpable, so I would like to construct what I believe is the strongest example on the side of majority opinion. Sam and Ruth are a self-absorbed yuppie couple with a small child. They are throwing a dinner party for some socially prominent people who can help both Sam's and Ruth's careers and their social standing, and they are quite obsessed with making sure the party is a success. They put their child in the bathtub and begin drawing bathwater, but just then the first guests begin to arrive. Sam and Ruth both go downstairs to greet the guests, both realizing that the child would be in grave danger if they failed to return and turn off the water, but both believing correctly that at the rate the tub is filling, they will have plenty of time to return to the child after they have welcomed the guests. Of course, when they greet their guests they become so absorbed with making the right impression that both forget about the child, with tragic consequences.

If there is ever a case of culpable negligence, this is it. Sam and Ruth are not morally attractive people. And their moral shortcomings have

55. See Alexander, supra note 2; Holly Smith, Culpable Ignorance, 92 PHIL. Srud. 543 (1983); Michael J. Zimmerman, Negligence and Moral Responsibility, 20 Nous 199 (1986).

56. Cf. United States v. Short, 4 C.M.A. 437, 16 C.M.R. 11 (1954) (discussing prosecution for assault with intent to rape where American defendant claimcd he believed Japanese victim was expressing consent). 
played a role in their child's death. ${ }^{57}$ Still, I would argue, they did not act culpably. When they went downstairs they did not believe they were taking any substantial risk with their child, perhaps no more substantial a risk than we believe we are taking (for the sake of our careers) when we attend a workshop and leave our children with a sitter. Of course, once Sam and Ruth became engaged with their guests, the child's situation slipped out of their minds. And once the thought was out of their minds, they had no power to retrieve it. They were at the mercy of its popping back into mind, which it did not.

As Michael Zimmerman and Ishtijaque Haji have recently written, one is culpable only for acts over which one has control. ${ }^{58}$ If one is unaware that, say, someone has replaced the sugar on the table with poison, then one is not culpable for placing that poison in another's coffee and thereby killing her. For although one is in control of the conduct of placing the white substance in the coffee, the mistaken belief that it is sugar deprives one of the kind of control necessary for culpability. And what holds true for conduct taken in ignorance of its nature or likely consequences also holds true for the ignorance itself. One is not culpable for one's ignorance unless one is in control of it. And one can be in control of

57. The fact that character defects play a role in agents' not adverting to risks leads Steven Sverdlik to reject what he calls the Aristotelian Strategy of linking the culpability of negligence to a past reckless act, the strategy favored by the authors in note 55 supra. See Steven Sverdlik, Pure Negligence, 30 AM. PHIL. Q. 137 (1993). The problem, however, is that it is impossible to prove the counterfactual proposition that an agent who forgets something important would have remembered it had he not had a particular character defect. And in the absence of such a showing, all that the agent can be blamed for is the character defect itself, not the inadvertence and risk-imposition that may or may not have been its product.

Sverdlik at one point implies that the burden should be on the negligent actor to show why he could not have adverted to the risk prior to the risk-imposition. See id. at 146. In other words, the actor needs to show the presence of a causally relevant excuse rather than the absence of a causally relevant character defect. The mere fact that it did not cross one's mind that there is something that should be attended to is not, for Sverdlik, such an excuse. But Sverdlik fails to give a convincing explanation for why it is not.

Jeremy Horder maintains that failing to advert to a high risk can be symptomatic of what he calls weak indifference. See Jeremy Horder, Gross Negligence and Criminal Culpability, 47 U. TORONTO L.J. 495 (1997). The weakly indifferent actor would not impose a high risk were he aware of it. Sam and Ruth in my example are weakly indifferent in Horder's terms. Horder deems such people criminally culpable, but, like Sverdlik, he fails to demonstrate how his position avoids punishment based on a character defect rather than a choice.

Finally, James Montmarquet argues that the negligent actor is culpable when his incorrect beliefs about risk are the result of an arrogant overconfident attitude. See James A. Montmarquet, Culpable Ignorance and Excuses, 80 PHIL. STud. 41 (1995). Althougli arrogance is surely an unattractive characteristic, Montmarquet does not adequately distinguish cases of certainty of one's beliefs from cases of beliefs held arrogantly. Are we "arrogant" in beheving that the Earth revolves around the Sun? Were pre-Copernicans "arrogant" in believing otherwise?

58. See Ishtiyaque Haji, An Epistemic Dimension of Blameworthiness, 57 PHIL. \& Phenomenological Res. 523 (1997); Michael J. Zimmerman, Moral Responsibility and Ignorance, 107 ETHICs 410 (1997). For an attempt to rebut Zimmerman, see James Montmarquet, Zimmerman on Culpable Ignorance, 109 ETHICs 842 (1999). 
one's ignorance only indirectly, say, by deliberately refraining from learning something while being aware that one is running an unjustifiable risk of dangerous ignorance.

Because the actor who fails to advert to a risk acts in ignorance of that risk, he is not culpable for taking it. He may or may not be culpable for some earlier act that he realized at the time could result in further ignorance of the kind that did result. But even if he were culpable, he would be culpable only for the earlier recklessness, not the consequential negligence. ${ }^{59}$

\section{The Arbitrariness of the Definition of Negligence and the Lines}

Between Negligence, Strict Liability, and Involuntariness

If one accepts my argument in the previous subsection that negligence is nonculpable, then the very concept of negligence, in contradistinction to strict liability and involuntariness, collapses. The "reasonable actor," the construct by which negligence is gauged, is supposed to be somewhere between God, who knows with certainty whether conduct will cause harm, and the negligent defendant, who underestimated a particular risk. That is, the reasonable actor is supposed to be aware of more than the negligent actor but less than God.

There is, however, no way to construct the reasonable person nonarbitrarily. All of us are ignorant of many risks. When is that ignorance the kind that the reasonable person would possess, when is it not, and why? If negligence were culpable, then we could give an answer: The reasonable person would not be ignorant of those risks the ignorance of which would render him culpable. But if ignorance is never culpable because we lack direct control over it, ${ }^{60}$ then we have no materials from which to construct a nonarbitrary "reasonable person."

For the very same reason, negligence must collapse into strict liability and involuntariness. Take the person who drives a new car off the lot, sets the cruise control at the speed limit, and then, when the speed limit

59. It is sometimes suggested that neghigence, though nonculpable, especially when it is "gross," is strong evidence that the putatively negligent defendant was really reckless. That is, gross negligence serves as a convenient proxy for advertence to risk because it is rare that someone engages in the highly risky conduct that gross negligence involves without adverting to the risk. If this is the case, then perhaps criminal liability for gross negligence can be justificd along the same lines as strict liability is sometimes defended, namely, as a means of ensuring that the truly culpable do not escape punishment without at the same time ensnaring too many of the truly nonculpable. (The courts routinely permit such implicit "conclusive presumptions" of culpability even while rejceting explicit conclusive presumptions. Compare Dressler, supra note 1, at 126-28, with id. at 64-65.) I take no position here on this argument for criminal liability based on negligence, either regarding its empirical premise or regarding its normative one.

60. See Zimmerman, supra note 58. 
changes, cannot disengage the cruise control in time to avoid speeding. ${ }^{61}$ If he were deemed guilty of a traffic offense and punished, would this represent punishment for involuntary conduct, strict liability punishment, or punishment for negligence? The case for involuntariness is that for the period the cruise control was stuck, the defendant was a passenger in a runaway vehicle and had no control over its moveinent. On the other hand, he did voluntarily bring the car to its original speed and engage the cruise control, which from that standpoint makes his case seem like one of strict liability. In other words, depending on the point in time from which we begin to tell the story of the crime-the time at which the driver engages the cruise control versus the time at which he tries to slow down-his conduct can appear to be either one thing or the other. Without a culpable act to mark the beginning of the story of the crime, the choice of when to begin it, and thus whether it is a case of strict liability or a case of involuntariness, is purely arbitrary.

For the very same reason, given that negligence is nonculpable, the case could also be characterized as one of negligence. The defendant failed to advert to the condition of his cruise control that would cause it to inalfunction. The risk of inalfunction was high-in fact, one. His failure so to advert-his ignorance-was nonculpable; but so is all ignorance.

\section{CONCLUSION}

If negligence is not a type of culpability, then recklessness can serve as a comprehensive, unified conception of criminal culpability. It can encompass knowledge, purpose, and wilful blimdness. And it can serve as the mens rea for complicity as well as for completed "attempts." Criminal culpability is always a function of what the actor believes regarding the nature and consequences of his conduct and what the actor's reasons are for acting as he does in light of those beliefs. Recklessness, minus its substantiality of risk requirement, perfectly expresses these two dimensions of culpability. ${ }^{62}$

6I. See Alexander, supra note 2, at 90-92 (discussing State v. Baker, 571 P.2d 65 (Kan. Ct. App. 1977)).

62. I should mention and respond briefly to several points brought up during the discussion of this Essay at the conference on The Morality of Criminal Law.

First, Joshua Dressler in his Response to my Essay urges that the "substantiality" component of recklessness be retained but applied, not to the degree of risk that the actor believes he is imposing, but rather to the degree of unjustifiability that such risk imposition represents. See Joshua Dressler, Does One Mens Rea Fit All? Thoughts on Alexander's Unified Conception of Criminal Culpability, 88 CALIF. L. REv. 955, 957-958 (2000). In other words, Dressler would restrict recklessness to those conscious risk impositions that are not only unjustifiable, but substantially so.

I am uncertain whether Dressler's recommendation should be adopted. It is true that without it, my proposal would make one who commits even a very petty crime reckless regarding all the risks committing that crime creates. Thus, for example, if one were accidentally to kill in the commission of a petty crime, and one were aware that committing that crime increased the risk of such an accidental death, albeit only infinitesimally, one would have committed a reckless homicide. That result would 
not bother me, however, because I reject the materiality of results. See supra text accompanying note 43. One's culpability is the same as one's degree of recklessness, which is fixed at the point one commits the petty crime and does not turn on what harm occurs.

I should add here that an actor's mistaken belief that his risk-imposition is legally justifiable is, like mistakes of criminal law generally, nonexculpatory, unless, that is, the mistake is one regarding the necessity of the risk-imposition as opposed to the worthiness of the actor's goal. Thus, if someone mistakenly believes that imposing risks of serious harm on others is legally justified by the large thrill the actor receives from doing so, the actor is reckless. On the other hand, if the actor mistakenly believes that imposing a risk of serious harm on others is legally justifiable because it is the only way to avert a greater harm, or so he mistakenly believes, then unless his mistaken belief is recklessly held, he is not reckless in imposing the risk.

Second, several participants pressed me on the doctrinal implications of my thesis. In particular, they were concerned about the discretion and potential for its abuse that courts and juries would possess if their task was to find degrees of a single scalar form of culpability rather than to employ the current inperfect categories of purpose, knowledge, and recklessness. That is surely a point worth considering, and one I have not considered. However, I am doubtful that the current categories work as well as those pressing this objection assume. For example, the line between knowledge and recklessness is surely not a bright one. And the wilful blindness area is a morass. But the argument that the current doctrinal categories provide more and better guidance than a single scalar category of recklessness may nevertheless be correct, in which case my thesis has fewer doctrinal implications than it might otherwise have.

Third, Michael Moore, in private conversation, pressed me on what kind of consciousness or awareness of risk I require for recklessness. In particular, can a defendant be reckless if he "believes" that a risk exists, in the sense that he is disposed to act responsively to it, but is not fully conscious of that risk? We have often had the experience of driving successfully down a road for several minutes without being able to recall anything about our driving. We obviously adverted to the risks along the way and responded to them, but we were not fully conscious of them at the time and later cannot recall them. Aspects of riding a bieycle and other habitual activities frequently fall below the level of full consciousness. I am inclined to deem such low-level consciousness of risk to be sufficient for recklessness culpability, although I would want to consider the issue more fully than I have. My principal reservation about deeming low-level consciousness of risk sufficient for recklessness is that the actor may not have an adequate sense of the risk's magnitude, as opposed to its presence, to regard him as culpably indifferent.

Finally, several participants expressed reservations about having recklessness serve as the mens rea for inchoate crimes. Because a satisfactory response to this concern requires a complete reexamination of inchoate criminality, which space precludes in this Essay, I can only refer the reader to the article by Kim Kessler and me, which undertakes precisely that task. See Alexander \& Kessler, supra note 9. 